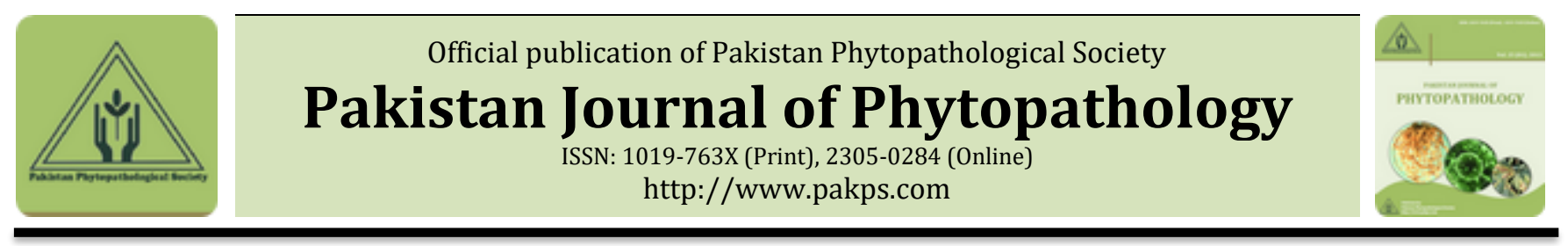

\title{
DETECTION AND IN-VITRO MANAGEMENT OF SEED BORNE MYCOFLORA ASSOCIATED WITH SUNFLOWER AND ZINNIA
}

\author{
aGulshan Irshad, aHira Gazal, aFarah Naz, bImran Hassan, aAmir Bashir, bSalman Ghuffar \\ a Department of Plant Pathology, PMAS Arid Agriculture University Rawalpindi, Pakistan. \\ b Department of Plant Breeding and Genetics, PMAS Arid Agriculture University Rawalpindi, Pakistan.
}

\begin{abstract}
A B S T R A C T
The present study was conducted to detect seed borne mycoflora associated with seven cultivars of sunflower (Helianthus annuus L.) and five cultivars of Zinnia (Zinnia elegans L.) by using Agar and Blotter paper methods. A total 12 genera of fungi were detected including; Alternaria alternata, Aspergillus flavus, Aspergillus niger, Cladosporium sp., Stemphylium helianthi, Penicillium sp., Fusarium oxysporum, Mucor sp., Fusarium moniliforme, Fusarium solani, Rhizocotonia solani and Rhizopus sp. The detected fungi depleted germination 10-30\%, 10-20\% and seedling mortality $10-17 \%, 10-12 \%$. in sunflower and Zinnia respectively. A comparative study was designed to evaluate three fungicides to control seed mycoflora at the rate of of $1.5 \mathrm{~g} / \mathrm{kg}, 2.0 \mathrm{~g} / \mathrm{kg}, 2.5 \mathrm{~g} / \mathrm{kg}, 3.0 \mathrm{~g} / \mathrm{kg}$, Maximum germination percentage was attained in case of seed dressing with Topsin M-70 followed by Bayton and Dithane M-45 at the rate of $3.0 \mathrm{~g} / \mathrm{kg}$.
\end{abstract}

Keywords: Seed borne, Mycoflora, Sunflower, Zinnia, Chemical Evaluation.

\section{INTRODUCTION}

Sunflower (Helianthus annuus L.) is an annual ornamental herb also grown as an oil seed crop. During the year 2014-15 in Pakistan, it was planted over an area of 353 thousand hectares producing 178 thousand tons annually which was 4 percent less than the previous year (GOP, 2015). The main reasons for its low productivity are the insect attack at maturity, lack of quality seed and number of parasitic and non-parasitic diseases (Ashfaq and Aslam, 2001). So far, more than dozen air, soil or seed-borne diseases have been recorded (Mukhtar, 2009). Seed borne diseases are of prime importance due to the detrimental effects on germination as well as reduction in oil contents and aesthetic value of the plant is also decreased due to poor stand and bad physical appearance. The edible oil plays a vital role in the economy of the country and 13.4 percent is contributed mainly by sunflower cultivars with oil contents of 32-36 percent (Shah et al., 2005).

Zinnia (Zinnia elegans) are popular garden flowers, usually grown from seed. The seeds of zinnia mature in a

* Corresponding Author:

Email: gulshanirshadpp@gmail.com

(C) 2017 Pak. J. Phytopathol. All rights reserved. crowded, erect position, can keep moisture from rain or overhead irrigation and create ideal conditions for fungal growth and infection. Seed is basic input for the production of any plant, so it should be healthy and free of pathogens.

Sharfun Nahar et al., (2005) reported the association of large number of fungi with sunflower and zinnia seeds includes: Aspergillus flavus, A. niger, A. ocheraceus, Alternaria alternata, Fusarium solani, Penicillium digitatum, Rhizopus arrihizus, Acremonium fusidioides, Arthrobotrys oligospora, Bipolaris bisepta, Cephaliophora tropica, Chaetomium spinosum, Cladobotryum varium, Cladosporium cladosporioides, Emericella nidulans, Gonatobotrys simplex, Humicola grisea, Memnoniella echinata, Mucor mucedo, Myrothecium verrucaria, Phialophora verrucosa and Syncephalastrum racemosum. Most of the fungi are carried as spores on the seed surface and are relatively easy to control with seed dressings while some exists as mycelium deep within the seed, and therefore are more difficult to control. Most seed-borne diseases are controlled by treating seed with chemicals (Bhutta et al., 2001) or by seed dressing with antagonistic microorganisms. But chemical control is far faster acting than biocontrol and hence farmer demands 
the fast control of the disease. In case of seed borne diseases in ornamental plants, aesthetic value of the plant as a result of appearance of the disease will be affected negatively as it will lose its attraction by inadequate color of flowers, deprived growth of the plant resulting in other unpleasant effects. Keeping in view the current study was carried out to investigate incidence of seed borne mycoflora, efficiency of different seed health testing method for detection of pathogens, effect of pathogens on seed germination and chemical seed treatment for control of sunflower and zinnia seed borne pathogens.

\section{MATERIALS AND METHODS}

Collection of seed samples: Seven sunflower cultivars viz (Big smile, Moon Bright, Golden 1, SMH-917, Autumn beauty, DK-3849 and AG-7) and five zinnia cultivars (Dreamland, Crystal series, Zinnia chrysanthemum, Dahlia flower mix, Elegans dahlia flower) were taken from nurseries of Rawalpindi, Islamabad and NARC during 2014-2015. The seeds were collected in sterilized polythene bags and kept in a refrigerator at $4^{\circ} \mathrm{C}$ until used. Randomly 400 seeds were used in each treatment. (ISTA, 1993)

Detection of seed borne mycoflora: For the identification of seed borne mycoflora two standard methods i.e. Agar and Blotter plate method (ISTA, 1993) were employed for the isolation of fungi from sunflower and Zinnia seeds. Three hundred seeds were tested in each experiment. Seeds were surface sterilized in $1 \%$ sodium hypochlorite $(\mathrm{NaOCl})$ and rinsed with sterile distilled water. 5-10 seeds were placed on three layers of sterilized moistened blotter paper in a $9 \mathrm{~cm}$ diameter glass petri dish. For agar plate method, sterilized petriplates were poured with $10 \mathrm{~mL}$ of autoclaved Potato Dextrose Agar (PDA). After solidification of medium, ten surface sterilized seeds per plate were equidistantly placed aseptically. Plates were incubated at $25 \pm 2{ }^{\circ} \mathrm{C}$ for a week under alternating cycles of 12 hours day and night under fluorescent tube light. Seeds were examined under stereomicroscope with two light sources. Identification of fungi was done on the basis of habit characters. Confirmation of species was done with the help of compound microscope as referred by Barnett (1955), Melone and Masket (1964) and Nelson et al. (1983).

Inoculums preparation and pathogenicity tests: Cultures were purified by hyphal tip method and pure cultures of the isolated fungi were preserved in culture tubes which were kept in the refrigerator at $4^{\circ} \mathrm{C}$ foe 72 hours and used frequently. The inoculum of each isolate was prepared by using $1 \mathrm{gm}$ culture in $20 \mathrm{ml}$ distilled water and mixed with soil. Pathogenicity testing was carried out in plastic pots with five replications. Each pot (10 cm diameter) contained $200 \mathrm{gm}$ sterilized mixture ( 1 part field soil: 1 part manure: 1 part sand) and sowed with 20 seeds of sunflower cultivar, both sterilized and untreated lots. Similar protocol was used for other experiments keeping appropriate controls. (Shrestha et al., 2000)

Effect on germination: Germination tests were carried out to check the effect of the fungi on the growth and physiological processes of the seeds. Seeds naturally infected with seed borne fungi were examined for their effect on germination. Hundred seeds were placed on blotter paper and were rolled. Papers were put in polythene bags and incubated at $25 \pm 2{ }^{\circ} \mathrm{C}$ for $10-15$ days. Moisture was given to keep the paper wet. Seeds were placed without any pre-treatment. After 10-15 days, the papers were opened and seedlings were examined (Anwar et al., 1994).

Seed to plant transmission: Most frequent and high percentage infecting fungi was selected for this test i.e. $A$. alternata, as it was found in high frequency and percentage as compared to other fungi. Two hundred seeds naturally infected with $A$. alternata were placed on well moistened blotter paper at $25 \pm 2{ }^{\circ} \mathrm{C}$ under alternating cycles of 12 hours day and night fluorescent tube light for 7 days. Ten seeds were plated in each glass petri plate. After four days, the seeds were observed using stereoscopic microscope and from germinating seeds showing infection of $A$. alternata were transferred to pots filled with sterilized soil and placed at $28 \pm 2{ }^{\circ} \mathrm{C}$ in growth chamber. Isolations were made at regular intervals of 15 , 40, 80 and 100 days. Ten seedling / plant were uprooted and incubated on blotter paper after washing in running tap water. The germinating seeds, seedlings (hypocotyls, cotyledons and roots), leaves (dried intact and green leaves) and stem (nodes and internodes) were studied. A set of 100 healthy seeds were used as control and observations of the fungi infected seeds were compared with the control. Results were expressed in percentage (Singh, 1983).

in vitro management of seed borne mycoflora sunflower and zinnia: For the evaluation of the chemical, Poisoned Food Technique" (Dhingra \& Sinclair, 1993) was used. The chemicals tested were: Topsin M70, Dithane M-45) and Bayton against sunflower 
cultivars i.e. Golden-1, DK-3849 and AG-7, and one of zinnia i.e. Crystal series having infection of many fungi were selected for this experiment. Seeds of sunflower and zinnia naturally infected with seed borne fungi were treated with these fungicides @ 1.5 g, $2.0 \mathrm{~g}, 2.5 \mathrm{~g}$ and $3.0 \mathrm{~g} / \mathrm{kg}$ and placed in Potato Dextrose Agar in Petri plates. Plates were incubated at $25 \pm 2{ }^{\circ} \mathrm{C}$ for 7 days. Seeds were also plated without any treatment of fungicide for the purpose of control. After 7 days, seeds were observed and the data was recorded. Growth inhibition was calculated as:

Percent inhibition of mycelial growth in treated plates was calculated

Percent Inhibiton $(\mathrm{I})=\frac{\mathrm{C}-\mathrm{Z}}{\mathrm{C}} \times 100$.

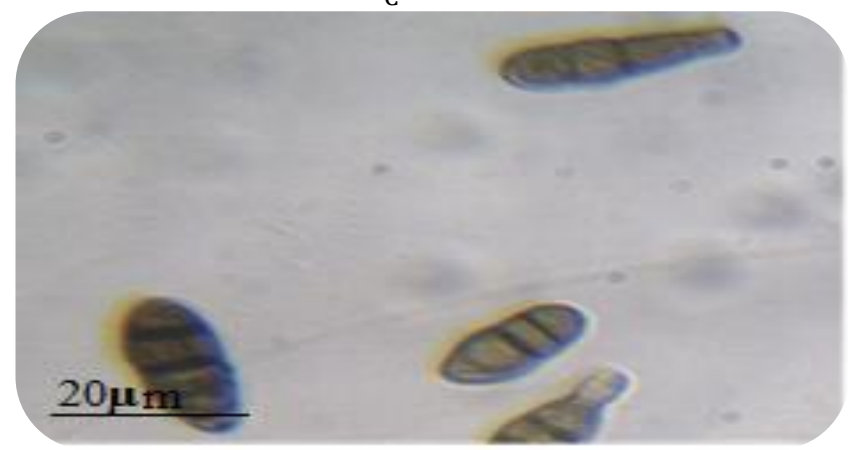

Figure 1. Alternaria alternate

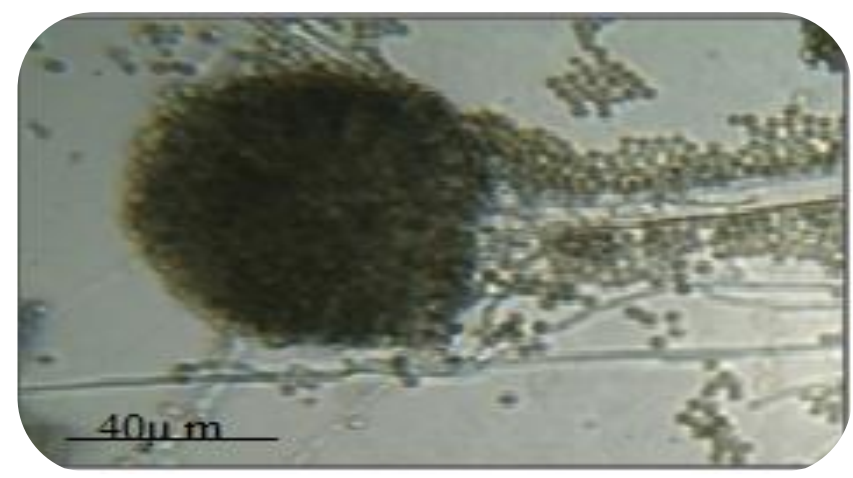

Figure 3. Aspergillus niger

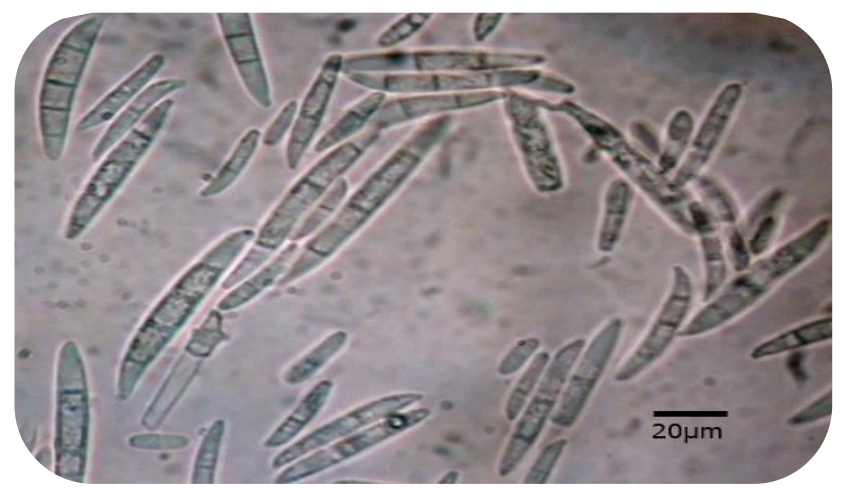

Figure 5. Fusarium solani

\section{RESULTS AND DISCUSSION}

Detection of seed borne fungi: Detection methods, i.e. blotter paper and agar plate method, recovered 12 genera of fungi viz. Alternaria alternata, Aspergillus flavus, Aspergillus niger Fusarium oxysporum, F. moniliforme, F. solani, Rhizopus sp, Rhizoctonia solani, Mucor sp., Stemphylium helianthi, Penicillium sp, Cladosporium sp were included (Table 1). All the fungal flora were characterized according to their cultural and morphological studies. It was evident from the results that Agar plate method was very effective as compared to the blotter paper method. These results are in close conformity with Afzal et al., 2010. (Figure 1).

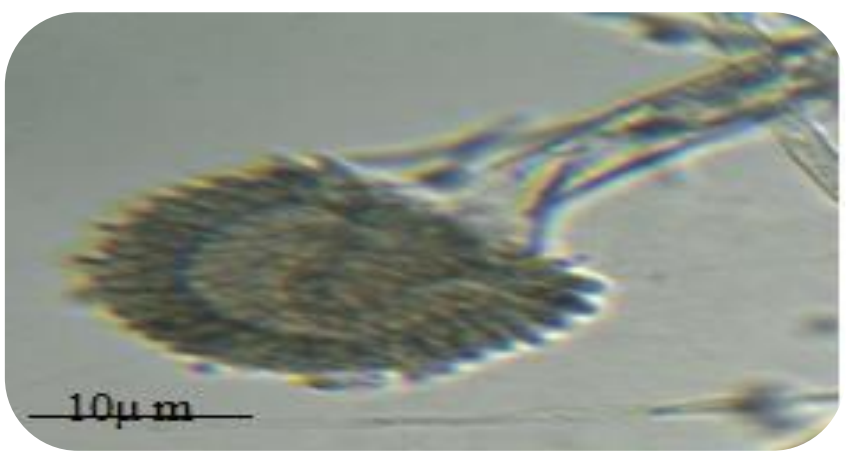

Figure 2. Aspergillus flavus

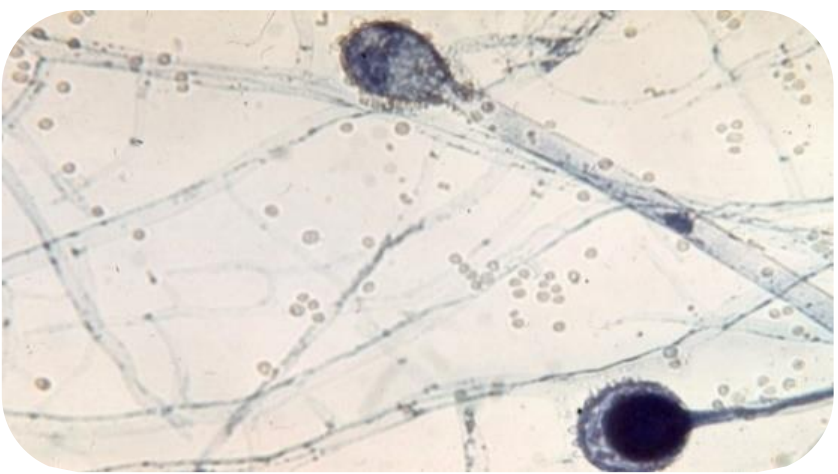

Figure 4. Mucor sp.

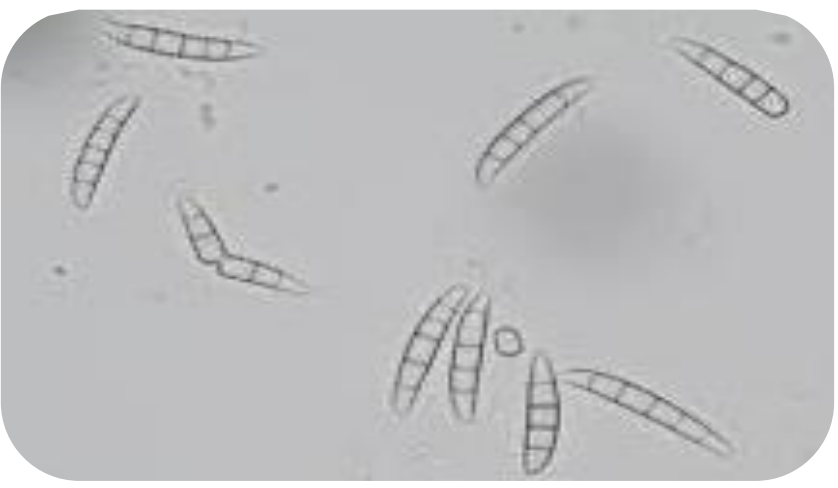

Figure 6. Fusarium oxysporum 
Pak. J. Phytopathol., Vol. 29 (01) 2017. 07-16

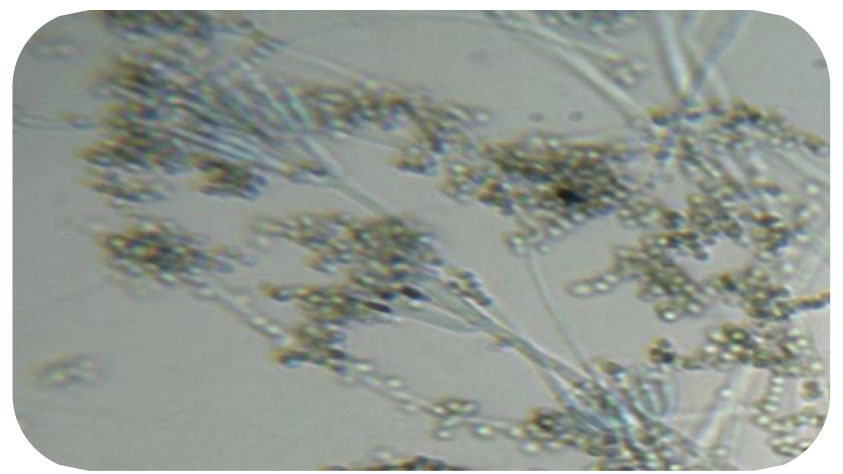

Figure 7 Penicillium sp.

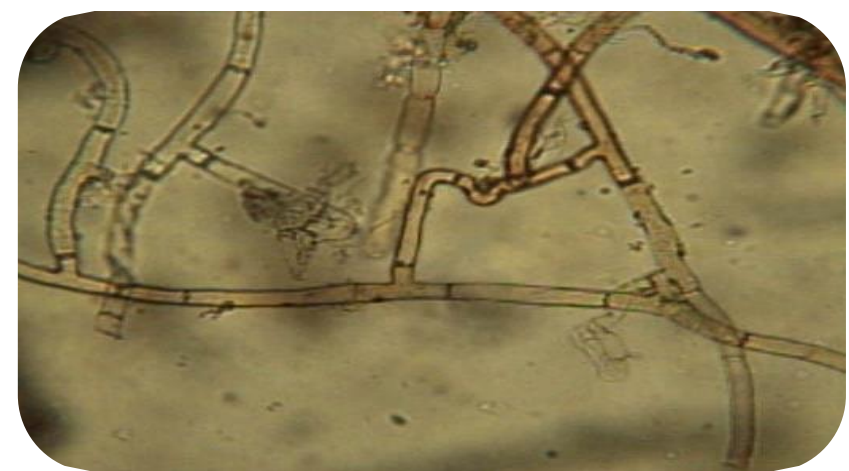

Figure 8. Rhizoctonia solani

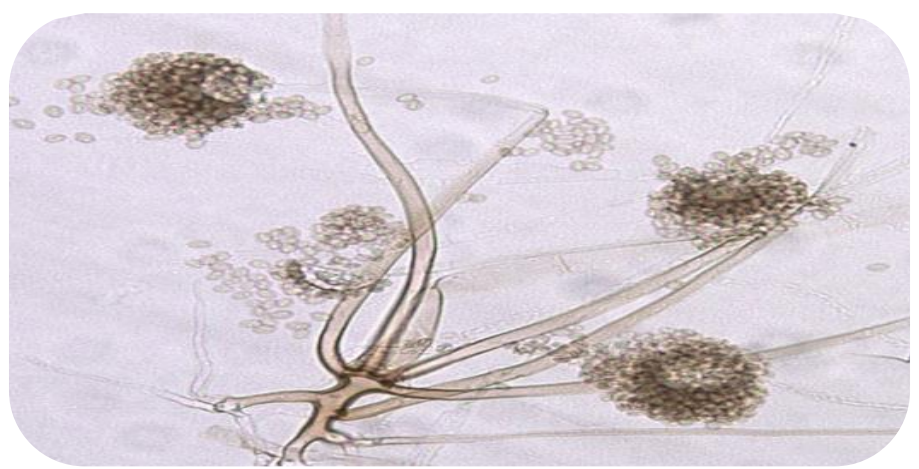

Figure 9. Rhizopus sp.

Table 1. Percent recovery of fungi in different varieties of sunflower and zinnia

\begin{tabular}{|c|c|c|c|}
\hline Plant & Varieties & Fungi & Percentage \% \\
\hline \multirow[t]{23}{*}{ Helianthus annuus } & \multirow[t]{2}{*}{ Big smile } & Alternaria alternata & 25 \\
\hline & & Aspergillus flavus & 5.0 \\
\hline & \multirow[t]{2}{*}{ Moon bright } & Aspergillus niger & 10 \\
\hline & & Aspergillus flavus & 3.0 \\
\hline & \multirow[t]{5}{*}{ Golden 1} & Alternaria alternata & 35.3 \\
\hline & & Cladosporium sp. & 1.0 \\
\hline & & Aspergillus flavus & 2.2 \\
\hline & & Aspergillus niger & 2.1 \\
\hline & & Stemphylium helianthi & 1.5 \\
\hline & \multirow[t]{3}{*}{ SMH-917 } & Penicillium sp. & 1.0 \\
\hline & & Fusarium охуsporum & 1.0 \\
\hline & & Mucor sp. & 0.5 \\
\hline & \multirow{2}{*}{ Autumn beauty } & Aspergillus niger & 3 \\
\hline & & Fusarium moniliforme & 1.6 \\
\hline & \multirow[t]{4}{*}{ DK-3849 } & Alternaria alternata & 28 \\
\hline & & Fusarium solani & 2.0 \\
\hline & & Cladosporium sp. & 0.8 \\
\hline & & Stemphylium helianthi & 1.0 \\
\hline & \multirow[t]{5}{*}{ AG-7 } & Aspergillus niger & 2.4 \\
\hline & & Rhizocotonia solani & 1.3 \\
\hline & & Rhizopus sp. & 0.3 \\
\hline & & Alternaria alternata & 30 \\
\hline & & Stemphylium helianthi & 0.5 \\
\hline \multirow[t]{6}{*}{ Zinnia spp. } & Dreamland & Alternaria alternata & 27 \\
\hline & \multirow[t]{2}{*}{ Crystal series } & Aspergillus niger & 3.1 \\
\hline & & Alternaria alternata & 3.1 \\
\hline & Zinnia chrysanthemum & Alternaria alternata & 2.4 \\
\hline & Dahlia flower mix & - & - \\
\hline & Elegans dahlia flower & - & - \\
\hline
\end{tabular}


In vivo screening of seed borne mycoflora associated with sunflower and zinnia by using germination method: Twelve seed samples naturally infected with various seed borne fungi were selected for seed germination test. The test was designed to analyze and assess the degree of effect of the seed borne fungi on the germination ability of the seeds. These samples were found to be infected with A. alternata, Aspergillus flavus, Aspergillus niger , Cladosporium sp., Stemphylium helianthi, Fusarium spp., Mucor sp., Rhizoctonia solani and Rhizopus sp. The major fungus isolated was A. alternata with highest percentage of recovery from the seed samples.

It was found that germination of the seeds was effected by these fungi as compared to healthy seeds. Viability of fungi was reduced to a considerable extent. It was observed that seed samples having infection of $A$. alternate were having much reduced germination percentage in all seed samples and developed more number of dead/un-germinated seeds and abnormal seedlings. Infected seed samples of sunflower i.e. Big smile, Golden-1, DK-3849, AG-7 and zinnia i.e. Dreamland and Crystal series were the varieties having lower germination (Table 2) and it was correlated with the infection of $A$. alternata. All these samples were infected with $A$. alternata. Moreover, it was also noticed that the samples with infection of greater number of fungi were having the lower germination and the samples infected with other fungi along with the A. alternata, were having the lowest germination percentage. This was due to the combine effect on the seed. The lowering of germination may be due to the usage of the energy rich compounds by these fungi that are required for the proper germination. Moreover, location of fungi in the seed also plays the role in the seed ability to germinate. Zinnia varieties; Dahlia flower mix and Elegans dahlia flower did not showed any fungi and its germination percentage was found to be highest among zinnia and sunflower varieties. AG-7 and Golden-1 was having the lowest germination which may be attributed to the fact that while isolating the fungi, higher numbers of fungi were isolated from these two varieties and both of these were also infected with $A$. alternata with high recovery percentage.

Of various disease causing organisms, fungi are known to be primarily involved in seed and seedling complex disorders and subsequently in the causation of adult plant diseases. A study was conducted to know the effect of mycoflora on germination of sunflower seeds and seed borne fungi caused abnormalities up to 30 percent. Rotted seeds were observed more in the samples having infection of A. alternata. Moreover, number of abnormal seedlings was also higher in the A. alternata infected seed samples. The seed samples having high infection of $A$. alternata alone reduced the germination to same extent when its infection was low. In combination with other pathogens, the germination percentage was reduced more as compared to other seed samples having infection of only single pathogen.

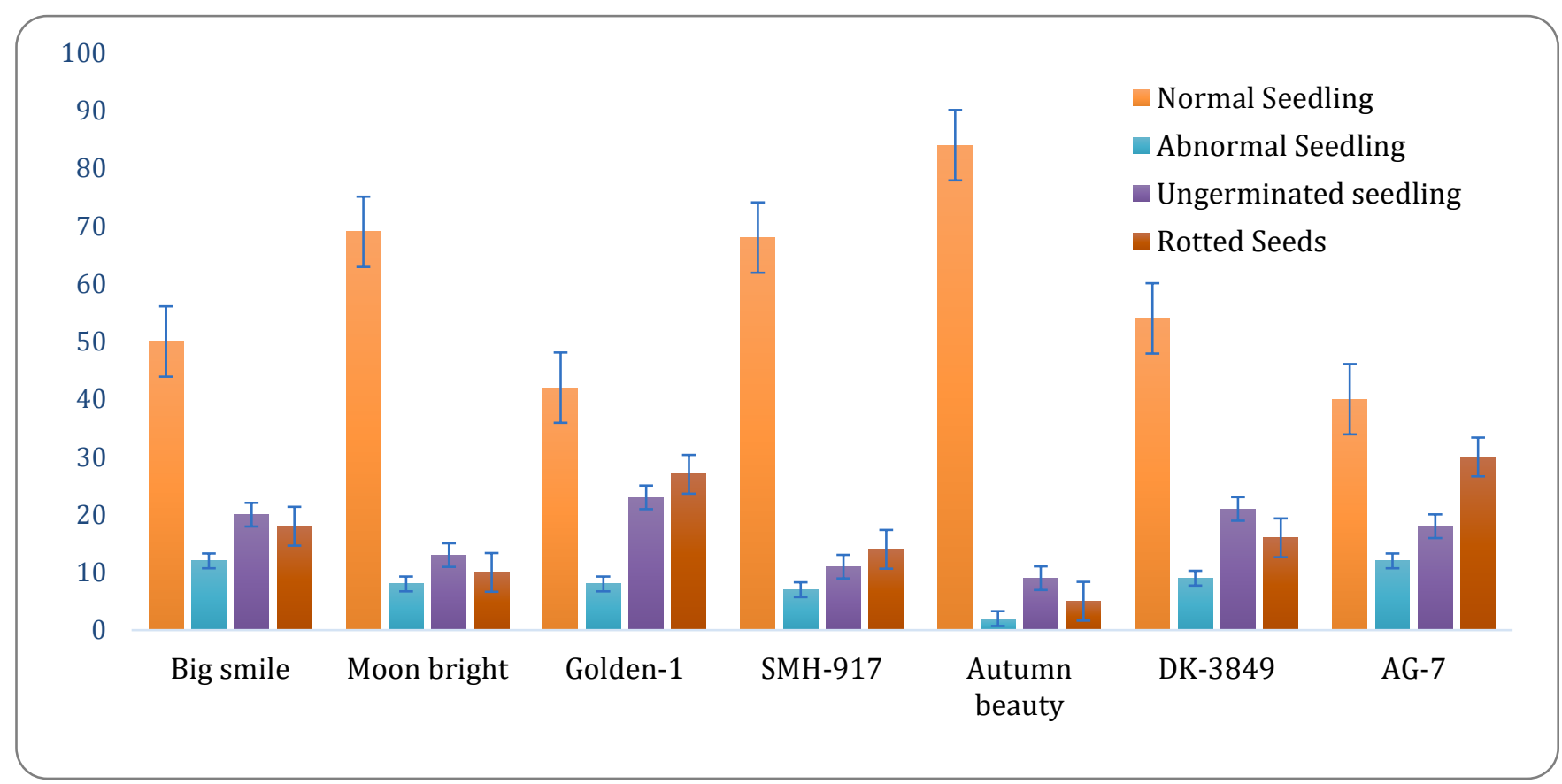

Figure 10. Germination percentage of Sunflower varieties 


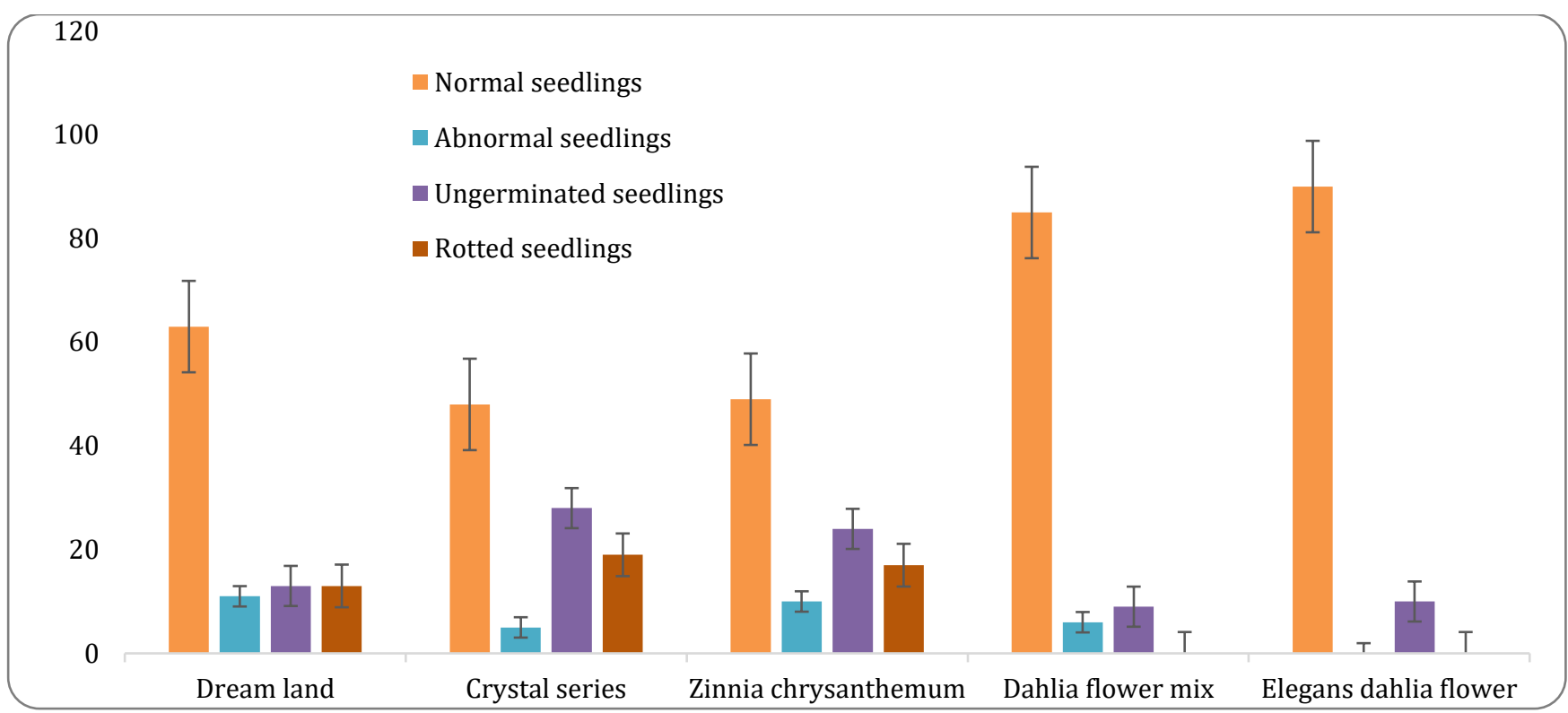

Figure 11. Germination percentage of Zinnia varieties

Seed to plant transmission: Alternaria alternata was recorded up to 35.3 percent on seed within five days using blotter paper method. Fungus started sporulation on some seeds after one day of incubation at 25 on blotter paper. The seeds were covered by the fungal growth in 35 hours of incubation, showed no sign of germination and the germinating seedlings were severely affected. One hundred infected seedlings were transferred in pots individually. Isolations were made at interval of 15, 40, 80 and 100 days by uprooting of 10 seedlings per plant. The dying seedlings were incubated by component plating technique. Hypocotyl and cotyledons were found infected up to 90 percent and root up to 80 percent in sunflower (Table 3) while in zinnia hypocotyl and cotyledons and roots were found infected 80, 85 and 65 percent respectively (Table4). From sunflower, isolation frequency of the pathogen from surviving plants was 30, 45 and 65 percent in dried leaves and 2 and 5 percent in green leaves at the 40, 80 and 100 days germination respectively. While in the stem, it was 15, 20 and 30 percent. On whole, percentage recovery of $A$. alternata was very low from the green parts. While in zinnia, isolation frequency from surviving plants in dried leaves was same as in sunflower i.e. 35 percent, 45 percent and 60 percent but in green leaves its percentage was slightly higher than sunflower as its frequency was 1,4 and 7 percent during 40,80 and 100 days respectively. In stem, 10 percent, 15 percent and 30 percent of isolation frequency was found during 40, 80 and 100 days. Infected plants showing lesions on stem were cut transversely at different levels, and the remaining pieces divided longitudinally and incubated on blotter paper. A. alternata was isolated after incubation. While results of component plating elaborated that infection of A. alternata in sunflower was higher in outer pericarp and slightly less in inner pericarp while only 2 percent infection was found to be associated with embryo. Almost similar results were observed in zinnia but endosperm infection was slightly higher than sunflower i.e. 45 percent (Table 5).

Chemical evaluation on seed borne fungi: Data regarding efficacy of three seed dressing fungicides expressed varied response for fungal elimination in seed lots. Similarly, seed viability was also affected by different fungicides at various doses. In control conditions Alternaria alternata, Aspergillus flavus, Aspergillus niger, Cladosporium sp., Stemphylium helianthi, Penicillium sp., Fusarium oxysporum, Mucor sp., Fusarium moniliforme, Fusarium solani, Rhizocotonia solani and Rhizopus sp.

Maximum control against fungal flora was observed at the rate $3 \mathrm{~g} / \mathrm{kg}$ of Topsin M-70. Three sunflower seed samples i.e. Golden-1, DK-3849 and AG-7 and one zinnia i.e. Crystal series infected with A. alternata, Rhizoctonia sp., Rhizopus sp., Aspergillus niger, A. flavus, Cladosporium sp., Fusarium solani, Stemphylium helianthi were selected for the test. Topsin M-70. showed good results. The results produced by this fungicide vividly explain its efficiency to control the seed borne diseases. It was seen that at dose of $2.5 \mathrm{~g} / \mathrm{kg}$ in Golden-1, $A$. 
alternata was eliminated (Table 6) while in other fungicides, results were not that much promising. Trace amount of pathogen was still associated with the seeds even at $3.0 \mathrm{~g} / \mathrm{kg}$ of dose e.g. Bayton and Dithane M-45 (Table 7 and 8). Bayton and Dithane M-45 at dose of $2.5 \mathrm{~g} / \mathrm{kg}, 2$ percent and 3.5 percent of the Table2. pathogen still existed respectively. Moreover, the surviving capability of A. alternata was revealed and it was observed that the pathogen has the strong ability to survive even at higher doses of the fungicides. The order for the efficiency of fungicide was: Topsin M-70 $>$ Bayton $>$ Dithane M-45.

\begin{tabular}{|c|c|c|c|c|c|c|c|c|c|c|c|c|c|c|c|}
\hline 䒕 & Sample & Fungi & D & & $t$ of $\mathrm{T}$ & $p \sin 1$ & {$[-70$} & & & & & Effec & of $\mathrm{D}$ & hane & $1-45$ \\
\hline \multirow{14}{*}{ 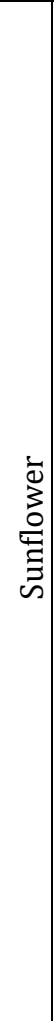 } & \multirow[t]{5}{*}{ Golden-1 } & Alternaria alternata & 35.3 & 8 & 1 & - & - & 11 & 5.5 & 2 & - & 13 & 7.0 & 3.5 & 1.0 \\
\hline & & Cladosporium sp. & 1.0 & - & - & - & - & - & - & - & - & - & - & - & - \\
\hline & & Aspergillus flavus & 2.2 & - & - & - & - & 0.2 & - & - & - & 0.3 & - & - & - \\
\hline & & Aspergillus niger & 2.1 & - & - & - & - & 0.2 & - & - & - & 0.2 & - & - & - \\
\hline & & Stemphylium helianthi & 1.5 & - & - & - & - & - & - & - & - & - & - & - & - \\
\hline & \multirow[t]{4}{*}{ DK-3849 } & Alternaria alternata & 28 & 6 & 0.5 & - & - & 9 & 4 & 1.5 & - & - & - & - & - \\
\hline & & Fusarium solani & 2.0 & - & - & - & - & - & - & - & - & - & - & - & - \\
\hline & & Cladosporium sp. & 0.8 & - & - & - & - & - & - & - & - & - & - & - & - \\
\hline & & Stemphylium helianthi & 1.0 & - & - & - & - & - & - & - & - & - & - & - & - \\
\hline & \multirow[t]{5}{*}{ AG-7 } & Aspergillus niger & 2.4 & - & - & - & - & - & - & - & - & - & - & - & - \\
\hline & & Rhizocotonia solani & 1.3 & - & - & - & - & - & - & - & - & - & - & - & - \\
\hline & & Rhizopus sp. & 0.3 & - & - & - & - & - & - & - & - & - & - & - & 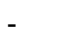 \\
\hline & & Alternaria alternate & 30 & 8 & - & - & - & 12 & 5.5 & 2.5 & 0.5 & 13.5 & 4.5 & 2.5 & 1.0 \\
\hline & & Stemphylium helianthi & 0.5 & - & - & - & - & - & - & - & - & - & - & - & - \\
\hline \multirow{2}{*}{ : } & \multirow{2}{*}{$\begin{array}{l}\text { Crystal } \\
\text { series }\end{array}$} & Alternaria alternate & 24 & 3 & 2 & - & - & 8 & 3.5 & 1.0 & - & 9 & 3.5 & 2.5 & - \\
\hline & & Aspergillus niger & 3.1 & - & - & - & - & - & - & - & - & - & - & - & - \\
\hline
\end{tabular}

Seed being a biological entity, is very often subjected to deterioration in storage due to microorganisms. Seed storage is an important parameter which is very much essential to realize the gains from the pains taken to produce seeds. Ways and means have to be standardized to improve storability and to protect the seeds from the onslaught of seed-borne and seed contaminating microorganisms during storage and transit.

In this study, the maximum numbers of fungi were isolated using agar plate method as compared to blotter paper method. These results were comparable to the findings of Afzal et al. (2010) in which seed borne fungi of sunflower was isolated using agar plate method (Godika et al., 1999) and is contrary to the findings of other scientists (Neergard, 1977; AlKassim and Monawar, 2000). Blotter paper method was found suitable for the detection of seed borne fungi mycoflora of cucurbits (Begum and Momin, 2000).

Seed borne fungi caused 20-30 percent reduction in germination in sunflower (Bhutta et al., 2001). Moreover, most of seed-borne diseases of sunflower decrease carbohydrate, protein, iodine and cholesterol 
contents values and increase quantity of acid (Ahmad et al., 1994). Low quality with discolored and reduced oil contents of sunflower seeds were reported to be caused by various species of Rhizopus (Mukhtar, 2009). Damaging of seeds, such as seedling and plant abnormalities, decreased seed vigor and seed death caused by seed-borne pathogens are not always recognized by users (Mukhtar, 2009). In the current studies, germination was reduced to even 60 percent by the seed borne fungi. Samples found ungerminated were covered with the conidia of A. alternata. Surviving seedlings showed no disease symptoms in the initial stage. However, such seedlings yielded the fungi upon incubation on artificial substrate. It may be due to the reason that fungus has slow process to produce symptoms in the plant parts. In the current study, stem infection was observed late. In highly infected stem, mycelium of the fungus was found inside the stem and symptoms were expressed late. It may be the reason that it takes long time to establish in the green parts of the plants. The pathogen was isolated successively from various parts of the plant which indicate that $A$. alternata is not able to invade the whole plant systemically. It may be concluded that seed to plant transmission take place by production of conidia by the fungus on leave and stem lesions. Seed to plant transmission studies conducted in downy mildew of sunflower, indicated that infected seeds gave rise to symptom less (latent infection) plants. The latent (symptomless) form of the disease quite often occurs so that one or two generations are grown before infection becomes evident (Sackston, 1981). The fungus usually invades the ovary and the pericarp, but fails to grow into the embryo. Our findings were identical to the findings of Bhutta et al., (2001). A. alternata showed high infection in pericarp and endosperm but low in embryo. The same infection percentage was found in zinnia. High infection and deep penetration in endosperm and embryo are considered the main factors in germination failure and preemergence mortality (Raut, 1983) that is why in germination test, low level of infection caused in embryo caused considerable more pre and post emergence mortality was observed. This might be due to the reason that the infection appears to spread from endosperm to embryo during germination and seedling emergence. These parts remain in close contact with each other for a longer period of time and cause pre and post emergence losses subsequently.
Ibiam et al., (2006) observed that systemic fungicides either inactivate or killed the pathogen in the seeds or as the germination seedlings starts. The metabolic activities of fungi could not be stopped at lower fungicides concentrations; it may be due to the fact that lower fungicides concentrations are unable to destroy few fungi. As the fungicides concentration increased, the metabolic activities of the fungi were destroyed completely. Similar trends were observed and as the concentration of the chemicals was increased, control of fungi was more and at $3.0 \mathrm{~g}$ of dose, no fungi were observed. Findings were in accordance to Bhutta et al., (2001) where the increased concentration decreased the population of fungi.

\section{CONCLUSION}

Sunflower (Helianthus annuus L.) considered a commercial oil crop all over the world, the crop is widely cultivated in Pakistan and in many countries all over the world. It is particularly used for production of edible oils as well as for seed consumption. Zinnia is also an ornamental plant and belongs to the same genera as a sunflower. Both is attacked by numerous same seed mycoflora which are responsible in a reduction of the seed quantity and quality. Among three fungicides Topsin-M, showed a significant result in the reduction of seed borne fungi in sunflower and Zinnia.

\section{REFERENCES}

Ashfaq, M. and M. Aslam. 2001. Resistance of different sunflower (Helianthus annuus L.) genotypes against the attack of Aphisgossypii Glover, Nezara viridula (L.) and Thrips tabaci Lind, in Field. J. Biol. Sci., 1: 941-945.

Anwar, S. A., A. R. Bhutta, C. A. Rauf, and M. S. A. Khan. 1994. Seed-borne fungi of pea and their role in poor germination of pea seed. Pak. J. Phytopathol. 6(2): 135-139.

Agarwal, V. K. and J. B. Sinclair. 1996. Principles of seed pathology. 2nd edt. pp. 16.

Ahmad, K. G. M., S. I. A. EL-Said, R. N. Fawzy, A. E. Badr and M. A. Abd-Allah. 1994. Pathological study on sunflower plant, chemical and biological control and seed oil content. Ann. Agric. Sci. Moshtoh. 3(3): 1529-1543.

Afzal, R., S. M. Mughal, M. Munir, K. Sultana, R. Qureshi, M. Arshad and M. K. Laghari. 2010. Mycoflora associated with seeds of different sunflower cultivars and its management. Pak. J. Bot. 42(1): 435-445. 
AlKassim M. Y. and M. N. Monawar. 2000. Seed-borne fungi of some vegetable seeds in Gazan province and their chemical control. Saudi. J. Biol. Sci., 7(2): 179-184.

Ahmed, I., S. Iftikhar and A. R. Bhutta. 1993. Seed borne microorganisms in Pakistan. Checklist 1991. PARC, Islamabad, Pakistan. pp.32

Baloch, Q. B., Q. I. Chachar and U. I. Panhwar. 2010. Effect of NP fertilizers on the growth and flower production of Zinnia (Zinnia elegans L.). J. Agric. Tech. 6(1): 193-200.

Basak, A. B and M. W. Lee. 2002. Prevalence and Transmission of Seed-Borne Fungi of Maize Grown in a Farm of Korea. Mycobiol. 30(1): 47-50.

Barnett, H. L. 1955. Illustrated Genera of Imperfect Fungi. 3rd ed., Burgess Publ. Co., Minneapolis, Minnesota, 241.

Begum, H. A. and A. Momin. 2000. Comparison between two detection techniques of seed-borne pathogens in cucurbits in Bangladesh. Pak. J. Sci. and Inds. Res. 43: 244-248.

Bhutta, A. R., M. M. R. Bhatti, I. Ahmad and I. Sultana. 2001. Chemical control of seed-borne fungal pathogens of sunflower. Helia. 24(35): 67-72.

Chakarbarti, D. K. and K. C. Basuchaudhary. 1980. Nature of action of cersan wet in controlling wilt disease of safflower caused by Fusarium oxysporium. Pestici. 15:24.

Chase, A. R. 1998. Alternaria diseases of ornamentals. West. Conn. turf and ornam. 1(3): 1-4.

Dawar, S. and A. Ghaffar. 1990. Location of fungi in sunflower seed. Pak. J. Bot. 22(2): 117- 120.

GOP. 2015. Economic Survey of Pakistan. 21.

Godika, S., K. Agrawal and T. Singh.1999. Incidence of Rhizoctonia bataticola in sunflower seeds grown in Rajasthan. J. Mycol. Pl. Path. 29(2): 255-266.

Huaiqin, Z., W. Jianshe, C. Shilin. 2009. Genetic diversity analysis of ornamental sunflower germplasm resources with RAPD. Mol. Plant Breed. 7: 73-78.

ISTA. 1993. International rules for seed testing. Proc. Int. Seed Test Assoc. Zurich, Switzerland.

Ibiam, O. F. A, C. I. Umechuruba and E. A. Arinze. 2006. Evaluation of the Efficacy of Seed Dressing fungicides (Bavistin, Benlate, Fernasan-D, Apron plus 50 DS, and DithaneM45) In the Control of Seed-Borne Fungi of Rice (Oryzae sativa L) Variety Faro 15 In Vitro. Sciencia Afr. 5(1): 1-10.
Jeffrey, K. K., P. E. Lipps and L. J. Herr. 1985. Seed treatment fungicides for control of seed borne Alternaria helianthi on sunflower. Pl. Dis. 69(2): 124-126.

Kaur, J., S. S. Chahal and K. S. Aulakh. 1990. Differential efficiency of different methods in detection and location of seed borne fungi in sunflower. Pl. Dis. Res. 5(1): 53-58.

Melone, J. P. and A. E. Maskett. 1964. Seed-borne fungi. Proc. Intl. Seed Test., Assoc. 29: 179-384.

Muhammad, A. and A. R. Khan. 1981. Perspective of edible oils research and production in Pakistan, PARC, Islamabad, pp. 9

Mukhtar, I. 2009. Sunflower disease and insect pests in Pakistan: A review. Afri. J. crop sci. 17(2): 109118.

Neergaard, P. 1977. Seed Pathology, Vol I and II, MacMillan Press, London,U.K, p.1187.

Nelson, P. M., T. A. Toussoun and W. F. O. Marasas. 1983. Fusarium species: An Illustrated Manual for Identification. Pennsylvania State Univ. Press, Univ. Park, Pennsylvania, pp.203.

Raut, J. G., and B. B. Bhombe. 1983. Efficacy of some fungicides and hot water in the control of seedborne infection of Macrophomina phaseolina in sunflower. Indi. Phytopathol. 36(2): 294-296.

Richardson, M.J. 1990. An Annotated list of Seed borne Diseases. Int. Seed Test. Assoc. Zurich, Switzerland. Pp. 320.

Relekar, N. N., Khalikar, P. V and P. S. Nikam. 2010. Survey and surveillance of Alternaria blight of safflower caused by Alternaria carthami in Marathwada region. J. Pl. Dis. Sci. 5(1): 195-197.

Shah, N. A., H. Shah and N. Akmal. 2005. Sunflower area and production variability in Pakistan: opportunities and constraints. Helia. 28: 165-178.

Sackston, W. E. 1981. The sunflower crop and disease: Progress, Problems and Prospects. Pl. Dis. 65(8):643-648.

Sadashivaiah, A. S., K. G. Ranganathaiah and N. D. Gowda. 1986. Seed health testing of Helianthus annuus with special reference to Macrophomina phaseolina. Ind. Phytopathol. 39: 445-446.

Sharfun, N., M. Mushtaq and M. H. Hashmi. 2005. Seedborne mycoflora of sunflower (Helianthus annuus L.). Pak. J. Bot. 37(2): 451-457.

Shreestha, S. K., S. B. Mathur and L. Munk. 2000. Alternaria brassicae in seeds of rapeseed and mustard, its location in seeds, transmission from 
seeds to seedlings and control. Seed Sci. Technol. 28: 75-84.

Shetty, H. S., S. B. Mathur and P. Neergaard. 1980. Sclerospora graminicola in pearl millet seeds and its transmission. T. Brit. Mycol. Soc., 74(1): 127-134.

Singh, D. V., S. B. Mathur and P. Neergaard. 1974. Seed health testing of maize. Evaluation of testing technique with particular reference to Drechslera maydis, Seed Sci. Technol. 2: 349-365.
Singh, I. D. 1983. New leaf spot disease of two medicinal plants. J. Agric. Madras. 70: 490.

Steel, R. G., and J. H. Dickey. 1997. Principles and procedures of Statistics. A Biometrical approach (3rd Ed.) McGraw Hill Book Co. Inc. New York. p. 178-182.

Sharfun-Nahar, M. Mushtaq and M. H. Hashmi. 2005. Seedborne mycoflora of sunflower (Helianthus annuus L.). Pak. J. Bot. 37(2): 451-457. 